\title{
Underground space development resulting from increased urban migration
}

\author{
Samuel T Ariaratnam ${ }^{1,{ }^{*}}$ and Bahaa Chammout ${ }^{2}$ \\ ${ }^{1}$ Beavers-Ames Chair in Heavy Construction, School of Sustainable Engineering and the Built Environment, Arizona State \\ Univ., P.O. Box 873005, Tempe, USA. \\ ${ }^{2}$ Department of Civil and Environmental Engineering, American University of Beirut, Beirut, Lebanon.
}

Global Journal of Engineering and Technology Advances, 2021, 08(02), 046-055

Publication history: Received on 22 May 2021; revised on 27 July 2021; accepted on 29 July 2021

Article DOI: https://doi.org/10.30574/gjeta.2021.8.2.0093

\begin{abstract}
Worldwide urbanization has resulted in the creation of so called "megacities" with populations of 10 million or more. It is estimated that $68 \%$ of the world's population will reside in urban centers by the year 2050 up from $55 \%$ in 2018 [1]. This pace of urbanization is staggering, especially in China where urban populations have more than doubled over the last 30 years, while urban land extent has more than tripled [2]. Today, urban planners and engineers are faced with challenging decisions regarding land management planning. To manage this population increase, there is a need to cultivate urban underground space to reduce congestion on the surface, control urban sprawl, and provide opportunities to re-purpose land for recreational space. This discussion paper provides a review of several recommended practices for urban underground space development addressing planning, intended function, and environmental sustainability/resiliency.
\end{abstract}

Keywords: Underground space; Urban migration; Construction; Urban planning

\section{Background}

Today, there is an increasing trend of people moving from rural areas to urban centers mainly driven by a pursuit of better employment opportunities. Urbanization is an important element of societal modernization and economic growth [3]. The United Nations estimates that by the year 2050, approximately 68\% of the world's population will inhabit urban cities, up from 55\% in 2018 [1]. Today, the most urbanized global regions are North America (82\%), Europe (74\%) and Oceania (68\%). Conversely, Asia (50\%) and Africa (43\%) remain mostly rural. Sustainable development remains a priority and depends largely on successfully managing urban growth. This entails finding ways to manage "urban sprawl", which puts pressure on urban transportation networks as well as utility systems such as water, sewer, power, telecommunications, and natural gas. Lack of land mass to accommodate population increase is a major issue facing cities resulting in considerable expansion outwards from the city center core.

To truly understand rapid urbanization, one only needs to look at the extraordinary urban transformation in China, where the pace of urban change is staggering. To put it into perspective, Beijing currently has a land area of greater than $16,800 \mathrm{~km}^{2}$ and a densely populated urban area of 3,937 $\mathrm{km}^{2}$ [4]. This translates to almost 6,000 people per km² living in Beijing. By comparison, the population density of China is only 150 people per $\mathrm{km}^{2}$. Continued migration from rural to urban centers has resulted in increasing population density. In 2010, China's urban population surpassed it rural population, thereby demonstrating a shift in demographics. According to Schneider and Mertes [2], the role of urban design and the provision of adequate services and housing to all segments of the population need to be addressed. In 2018, there were thirty-three Megacities worldwide with populations of greater than 10 million, with this number

\footnotetext{
${ }^{*}$ Corresponding author: Samuel T Ariaratnam

Beavers-Ames Chair in Heavy Construction, School of Sustainable Engineering and the Built Environment, Arizona State Univ., P.O. Box 873005, Tempe, , USA.
} 
expected to reach forty-three by 2030 [1]. Tokyo, Delhi, Shanghai, Sao Paulo, and Mexico City are currently the five largest metropolitan cities with estimated populations greater than 20 million each. China currently is home to six megacities with three others expected to surpass this threshold in the next few years. Exorbitant real estate prices in eastern cities such as Shanghai and Beijing, have resulted in many people being attracted to more affordable inland cities such as Chengdu, Xi'an, Wuhan, and Chongqing. All of these cities have experienced population increases of greater than 50\% since 2010. Shanghai, with a metropolitan population of 22.1 million is the $7^{\text {th }}$ largest urban area in the world. By comparison, New York City (21 million), London (10.8 million), Toronto (6.6 million), Sydney (4.5 million), and Cape Town (4.3 million) are major cities currently experiencing urban population growth [5].

To manage such rapid growth, cities are now seeing the benefits of cultivating their underground "real estate" to ease urban congestion. Sterling [6] identified strategic planning, environmental implications, planning issues, transport, financing, legal aspects, geotechnical aspects, underground technology, and research \& development as necessary considerations for the potential of urban underground space to create and maintain more livable cities. Cultivating underground urban space is not a new concept; however, it has now begun to be an important consideration in urban planning. Over the past 40 plus years, much research has been conducted in the area of urban underground space [7]. Currently, we are seeing increased development utilizing urban underground space with many unique applications. For example, a major urban underground space project in Wuhan, China was recently completed. Referred to as "Asia's largest underground urban complex", the Optics Valley Underground Space is currently the largest single underground space in China with a total construction area of $516,000 \mathrm{~m}^{2}$ and an excavation volume of around $1.8 \mathrm{million}^{3}$. The project contains commercial walkways lined with shops, entertainment, restaurants, public areas, and a transportation hub.

Today, there are many facility types that were historically built on the surface now being placed underground, thereby reducing congestion on the surface and controlling urban sprawl. As illustrated in Figure 1, retail shopping, transportation networks (i.e. roads and rail), parking lots, hospitals, financial institutions, restaurants, fitness facilities, and water treatment plants are examples of facilities that are now being constructed below ground in an effort to curb congestion. However, there still remains certain facilities that must be built above ground (i.e. airports, shipping, factories, wireless communications, outdoor recreational facilities).

Underground facilities tend to be more cost-effective when considering overall life cycle costs due to slower deterioration, reduced maintenance requirements, and longer design life. Munfah [8] suggested that the design life of many underground facilities exceed 100 years with some active tunnels being even older. For example, the London Underground was first opened in 1863, while the New York City Subway opened in 1904. Being protected from the elements serves to better preserve underground facilities.

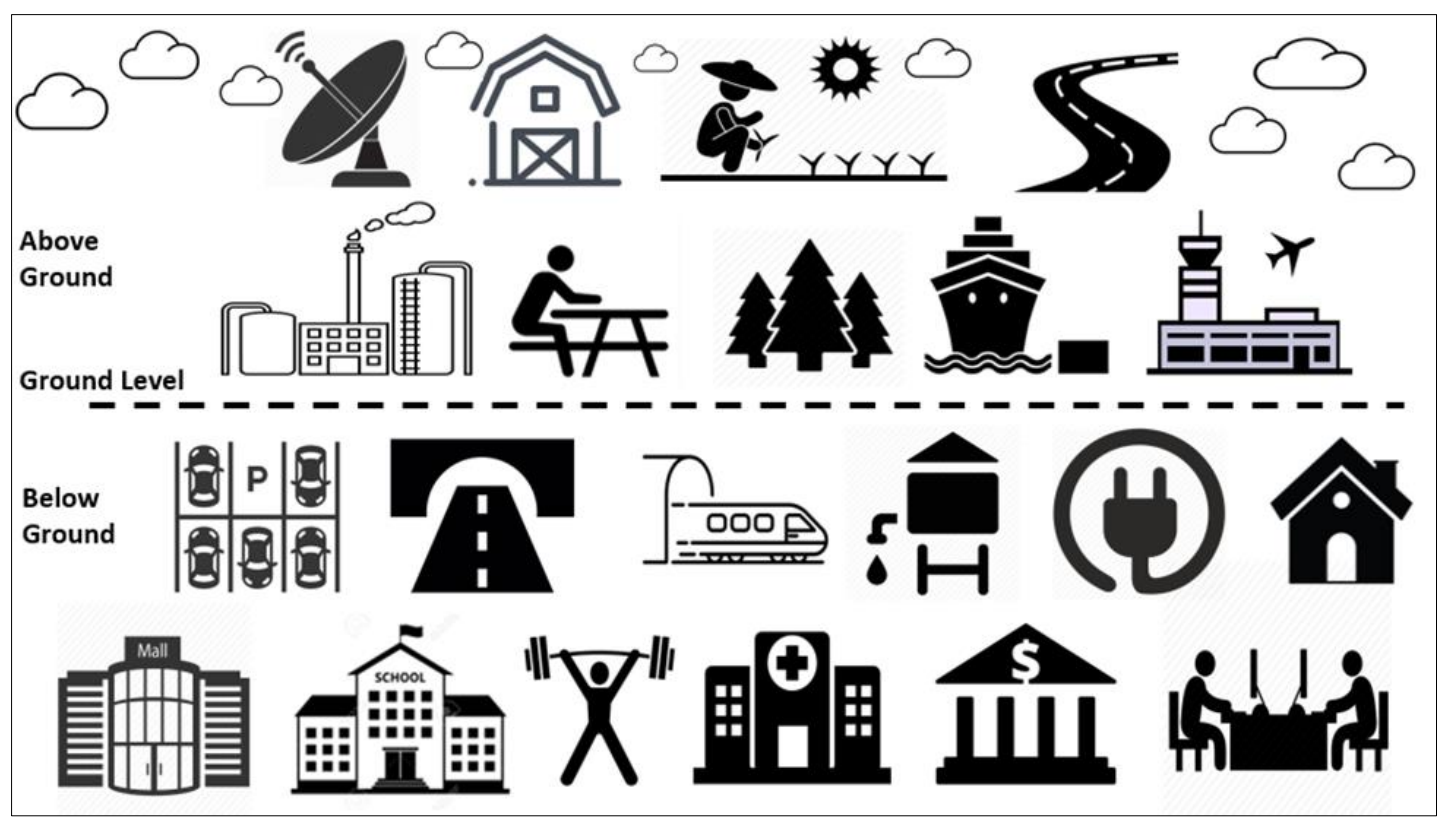

Figure 1 Example uses of urban underground space 
This paper provides a review of several current underground space practices for urban development including planning, intended function, and environmental sustainability/resiliency. As presented in Appendix A, there are numerous unique applications of urban underground space utilization worldwide as cities look to better plan and address increased migration.

\section{Planning}

Planning is a key element of any construction activity, especially when navigating the complexities of an urban environment compared to rural greenspace. A city's masterplan is the footprint for future growth and development with important considerations of urban design to best serve all segments of the population. Consideration of urban underground space utilization requires special planning involving many disciplines. Besner [9] discussed the fragmentation of disciplines in the planning of an urban underground space project. He concluded that pursuing such projects involves working with various actors as well as traditional professional collaborators. This interdisciplinary approach to planning requires only minimal knowledge of other professions; however, collectively they are required for success. This could include input from civil engineers, urban planners, geologists, architects, psychologists, first responder personnel, and other disciplines working together towards planning of urban underground space projects. In a study commissioned by the U.S. National Academies, Gilbert et al. [10] also concluded the need for adopting an interdisciplinary approach to cultivating underground space. The study defined engineering for sustainability as requiring engineers to move beyond traditional practice and consider their projects as part of a far larger physical and social system. In the context of urban underground space, it requires a multi-disciplinary approach including engineering scientists, planners, architects, and other professional from contributing disciplines. Organizations such as the Associated Research Centers for the Urban Underground Space (ACUUS), an independent international NonGovernmental Organization (NGO) with a strong focus on cities, actively promotes partnerships amongst all actors in the field of planning, research and uses of underground space in all its forms.

Sterling [11] identified four ingredients for the culmination of successful planning for cost-effective use of underground space in urban areas. This involves understanding the types of facilities and locations offering the best potential, resolution of legislative or administrative barriers to minimize project delays, identifying similar reference projects in other cities, and using local/regional planning to maximize the future benefit of the underground space.

Nelson [12] concluded that a holistic approach to planning is needed that captures aggregate attributes and emergent behaviors of the complex system of a region. She suggested a framework for modelling the functionality of complex urban infrastructure by identifying steps to help reduce costs and risks associated with urban underground construction.

Bobylev [13] suggested that there exist three key quantitative indicators to monitor urban underground space use. These indicators being developed urban underground space volume $\left(\mathrm{m}^{3}\right)$, density $\left(\mathrm{m}^{3} / \mathrm{m}^{2}\right)$, and space per person $\left(\mathrm{m}^{3} /\right.$ person). He concluded that the average urban underground space use density in cities is up to $0.05 \mathrm{~m}^{3} / \mathrm{m}^{2}$ with a volume per person being up to around $10 \mathrm{~m}^{3}$.

Bobylev [14] recognized urban underground space as being a valuable non-renewable resource that requires careful consideration during city planning. He recommended the implementation of elements including: three-dimensional planning; prioritizing underground space services; studying prospective functional and spatial interrelations between different types of infrastructures; and integrated assessment. He concluded that urban underground space must be considered in a city masterplan with sustainable development being a goal. Gilbert et al. [10] also concluded that sustainable and resilient urban development are important considerations for urban underground space.

Bartel and Janssen [15] concluded that strategic, comprehensive and holistic spatial planning is required to deal with the increasing range of demands for the utilization of underground space and to better manage associated conflicts related to space, responsibilities, and priorities. The findings of their study indicate that dedicated underground spatial planning regulations should replace common procedures in designating exclusive areas for certain purposes in order to ensure the sustainable use of underground space.

As documented in the literature, a comprehensive strategy must be implemented in planning for urban underground space. Successful execution requires an interdisciplinary approach with actors from various disciplines contributing to the planning of urban underground space projects. 


\section{Intended Function}

Another important consideration in the development of urban underground space is intended function. There are many examples of urban underground space development throughout the world with functions including shopping, residential, parking garages, water treatment plants, churches, trains, and other applications. The Canadian cities of Toronto, Ontario and Montreal, Quebec each have vast networks of varying functions beneath the downtown, city center core. Each of these cities have thirty plus kilometers of walkways connecting their underground worlds and enabling people to engage in daily activities beneath the surface. Appendix I is a description of numerous functions of urban underground space development throughout the world.

Bobylev [16] presented a case study of urban underground space use near Berlin, Germany. He analyzed data on underground structures as well as water supply, communications and sewerage. The study concluded that there was a significantly larger utilization ( $>60 \%$ ) of transportation (i.e., metro, roadway tunnel, and parking) compared to utilities (i.e., heating, water supply, sewerage), which constitute around 2 to $5 \%$ of underground space. Additionally, he suggests that the density of underground infrastructure in the sample area was in the range of 1 to $3 \mathrm{~m}^{3} / \mathrm{m}^{2}$ or 1 to $3 \mathrm{~m}^{3}$ on $1 \mathrm{~m}^{2}$ of area.

Yang and Sterling [17] studied the City of Shanghai and suggested that the role of developing urban underground space is as a contributor to the solution of reducing housing shortage, traffic congestion, and environmental pollution resulting from urban development. To achieve these goals, they recommended developing urban underground space for subways, subaqueous road tunnels, intake and discharge tunnels, underground parking, underground pedestrian passageways, and pipeline/conduit infrastructure.

Understanding the intended function(s) is imperative in urban underground space development. For example, underground parking facilities in a city center helps to alleviate congestion for people looking to park their vehicle with limited above-ground space available. Furthermore, retail opportunities can be generated through urban underground space such as shopping and restaurants in Shenzhen, China (Figure 2). It is imperative that proper wayfinding in the form of signs and directions be abundant in underground space environments with large pedestrian traffic. People, in general, often have psychological struggles when navigating underground with lack of directional guidance [10].

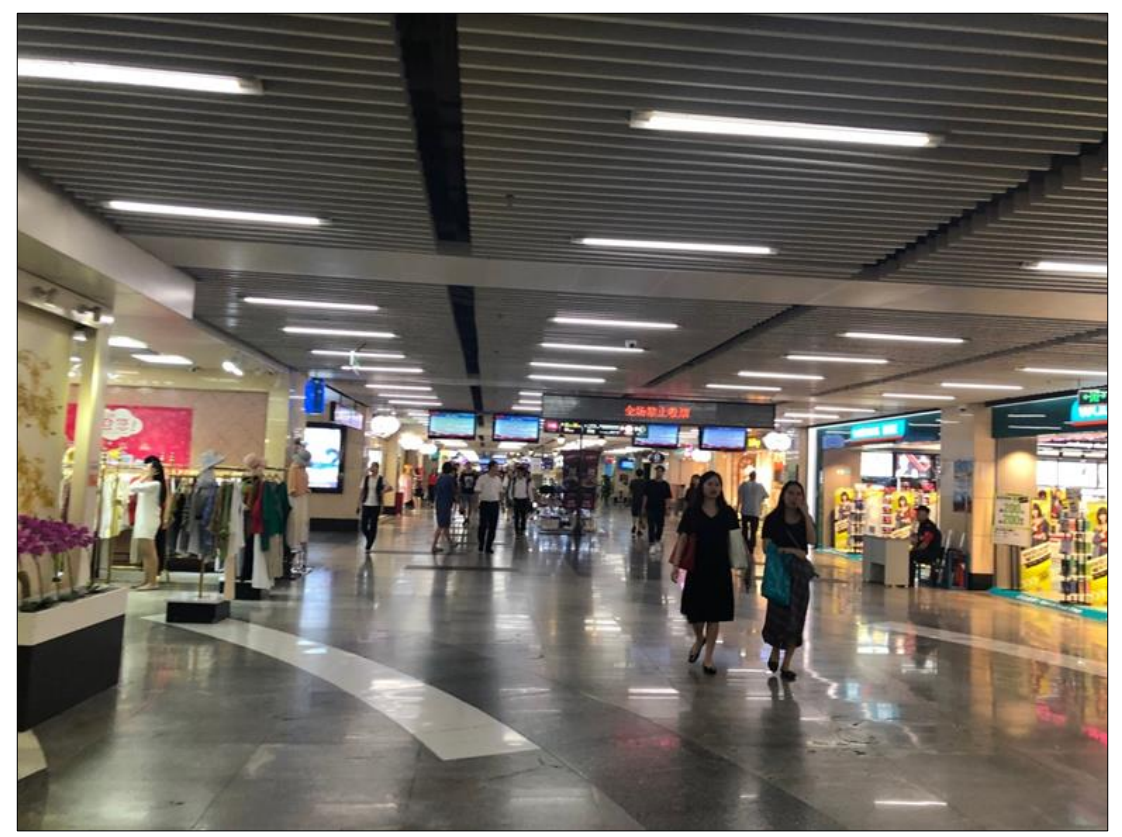

Figure 2 Example of underground retail space in Shenzhen, China

\section{Environmental sustainability/resiliency}

One often asked question is whether it is in fact more environmentally-friendly to build underground. Factors such as environmental decline and climate change have fostered the use of underground space for urban development by providing isolation from the elements. Underground space is sustainable and provides protection from the elements, 
thereby reducing power consumption and carbon footprint [8]. Additionally, the ground provides natural thermal isolation resulting in fairly uniform and moderate temperatures year-round [8]. Underground space provides benefits to surface activities through better air quality and reduced congestion due to reduction in vehicle traffic, not to mention increased resiliency against natural disasters such as earthquakes, tornadoes, hurricanes, ice storms, and flooding. Buried infrastructure incur far less damage than those above ground during natural disaster events.

Cui and Lin [18] studied and presented a detailed discussion of potential contributions and challenges in developing underground pedestrian systems within the context of sustainable urban development. They concluded that underground urban pedestrian systems present opportunities and challenges to achieving economic viability, environmental livability and social equity.

Much research has been conducted regarding the effects of urban heat island on surface infrastructure such as buildings and surface pavement $[19,20]$. Phelan et al. [21] suggested that direct impact of urban heat island could include changes in daytime and night time temperatures, while indirect impacts could be increased air conditioning loads, deteriorated air and water quality, reduced pavement lifetimes, and exacerbated heat waves. Urban underground infrastructure are shielded from the impact of urban heat island.

Han and Cornaro [22] discussed the need for utilizing urban underground space to achieve infrastructure resiliency in a current environment with multiple natural and manmade hazards that threaten cities in the form of shocks and stresses. The ability to react and restore themselves from these events is imperative to system recovery. They concluded that a lack of understanding of the subsurface environment can influence a city's resilience, as can the unplanned use of its underground space. This further supports the importance of planning to foster resiliency.

The use of new technologies to reduce operation and maintenance costs, make them safer, and extend their life cycle need to be explored. Urban growth has resulted in tremendous quantities of raw materials being required in the construction of these cities. Subsequently, production of construction material such as cement has increased significantly. For example, in 2018 alone, construction in China used about eight times the amount of cement as second place India, which is similar in population. From the perspective of conservation, we must make use of better materials keeping in mind that commonly used materials such as sand and gravel may be in short supply in the near [23]. This presents opportunities for research and development.

Furthermore, there must be consideration for new systems that increase the efficiency of energy (i.e., ventilation, temperature control, lighting, fire detection). Perhaps the use of lower temperature geothermal resources can reduce net emissions of greenhouse gases by exchanging heat from the earth to structure during the winter months and the opposite during the summer.

Numerous models have been developed to assist in evaluating impacts and sustainability of underground space development. Makana et al. [24] presented the development of a sustainable underground use resilience evaluation (SUURE) framework that enables the quantification of both spatial and temporal impacts of today's underground urban (re)development solutions in light of future economic, environmental and social changes. They used SUURE to evaluate the utilization of three types of Multi-Utility Tunnels (MUTs) in Birmingham, United Kingdom as an alternative to traditional open-cut methods of utility installation. As expected, the study found that tunneling resulted in significantly less surface disruption and subsequently environmental benefits. Ariaratnam et al. [25] developed an overall underground sustainability index rating (USIR) to quantify the sustainability of underground utility infrastructure projects by examining environmental impact, costs, and social impacts comparing four commonly used construction techniques. The study provides guidance for decision makers to better quantify proposed technologies for underground utility infrastructure projects based on sustainability factors. An example case study project in Portland, Oregon was used to demonstrate the application of the sustainability index rating model. These tools are intended to assist planners and decision-makers in better quantifying urban underground infrastructure options.

\section{Discussion}

The use of underground space should be considered as a part of urban city planning. The current pace of global urban change is overwhelming. Population growth in urban centers necessitates underground space utilization for improved resiliency and sustainable development. This underground "real estate" has proven to provide social and environmental benefits by relieving surface congestion and providing opportunities to re-purpose land for recreational space.

Gilbert et al. [10] concluded that more research and development is required to advance the use of urban underground space. The study recommends that a new framework be established to better enhance societal capacity and types of 
research, education, training and practices required for sustainable urban planning and underground infrastructure development. There is a current lack of stakeholders capable of designing, constructing, operating and maintaining effective and resilient underground facilities. Subsequently, governments, universities, and industry must be committed to develop the research capacity needed to promote urban underground space development.

Bobylev [26] discussed his views on transitioning to urban underground space from a high-density surface urban environment. He suggested that reduction in energy consumption with climate change benefits would be realized through development of underground space. Still, he opined that major challenges to an urban underground space agenda must include: 1) responsibility for managing/governing the transition; 2) use policy; 3) actual savings in land; and 4) how best to address global environmental change. This further supports the need to engage a diverse set of actors including civil engineers, urban planners, geologists, architects, psychologists, first responder personnel, and other disciplines working together towards planning, design, construction and operation of urban underground space.

Urban underground space is a societal asset that provides relief from the impacts of rapid urbanization. Planning must be included as part of the overall city master plan for better integration of functions. Added benefits of cultivating urban underground space include increased urban resilience due to the ability to better withstand natural and man-made hazards that threaten our cities in the form of shocks and stresses [22]. Overall, we need to train a new generation of stakeholders with diverse backgrounds to better address future urban underground space development.

Appendix I. Examples of urban underground development

\begin{tabular}{|c|c|c|}
\hline Application & Location & Description/Function \\
\hline $\begin{array}{l}\text { The Lowline } \\
\text { Underground Park }\end{array}$ & New York, USA & $\begin{array}{l}\text { To be completed in 2021, this project would transform an abandoned } \\
\text { trolley terminal on Manhattan's Lower East Side to the world's first } \\
\text { underground park. }\end{array}$ \\
\hline $\begin{array}{l}\text { Louisville Mega } \\
\text { Cavern }\end{array}$ & Kentucky, USA & $\begin{array}{l}\text { A former limestone mine restored into a tourist attraction, with } \\
\text { offerings including tram-guided tours, zipline tours, a ropes course, a } \\
\text { mountain bike park, and annual holiday lights display. }\end{array}$ \\
\hline Vegas Loop & Nevada, USA & $\begin{array}{l}\text { Completed in } 2021 \text {, Vegas Loop is a high-speed underground public } \\
\text { transportation system that can carry around } 4,400 \text { passengers per } \\
\text { hour. }\end{array}$ \\
\hline Dixia Cheng & Beijing, China & $\begin{array}{l}\text { A Cold War-era bomb shelter for more than } 85 \text { square kilometers that } \\
\text { was turned into a touristic attraction. }\end{array}$ \\
\hline $\begin{array}{l}\text { The Huaifang Water } \\
\text { Recycling Plant }\end{array}$ & Beijing, China & $\begin{array}{l}\text { Built underground to save valuable land. It is the largest underground } \\
\text { water recycling plant in Asia, and it is capable of treating } 200 \text { million } \\
\text { cubic meters of sewage a year. }\end{array}$ \\
\hline $\begin{array}{l}\text { Quzhou Sports } \\
\text { Campus }\end{array}$ & Quzhou, China & $\begin{array}{l}\text { Upon its completion in } 2021 \text {, this sports center will feature a stadium, } \\
\text { a pool, and other buildings, all hidden in green slopes. }\end{array}$ \\
\hline $\begin{array}{l}\text { Optics Valley } \\
\text { Square }\end{array}$ & Wuhan, China & $\begin{array}{l}\text { Titled "the largest underground urban complex in Asia" with a total } \\
\text { area of } 146,000 \text { sq } \mathrm{m} \text { of floor space. The complex includes three } \\
\text { subway lines, two utility tunnels, a road tunnel, and public spaces, } \\
\text { allowing the daily passenger flow to reach } 400,000 \text { people a day. }\end{array}$ \\
\hline $\begin{array}{l}\text { Bohai Strait Cross- } \\
\text { Sea Traffic Way }\end{array}$ & $\begin{array}{l}\text { Bohai Strait, } \\
\text { China }\end{array}$ & $\begin{array}{l}\text { Planned to be built by } 2026 \text { for an estimated } \$ 36 \text { billion, the } 123 \text { - } \\
\text { kilometer tunnel would connect the port cities of Dalian in Liaoning } \\
\text { Province and Yantai in Shandong, cutting the travel time between the } \\
\text { two places from eight hours to just } 40 \text { minutes. }\end{array}$ \\
\hline $\begin{array}{l}\text { Bupyeong } \\
\text { Underground } \\
\text { Shopping Mall }\end{array}$ & $\begin{array}{l}\text { Bupyeong, } \\
\text { Japan }\end{array}$ & An underground shopping mall featuring more than 1,400 stores. \\
\hline $\begin{array}{l}\text { ECO Cycle - } \\
\text { Automated Cycle } \\
\text { Storage }\end{array}$ & Japan & $\begin{array}{l}\text { Currently there are } 50 \text { parking stations in Japan. With a width of } 7 \\
\text { meters, each has enough depth to store } 144 \text { bicycles, along with a } \\
\text { retrieval time of just } 13 \text { seconds. }\end{array}$ \\
\hline
\end{tabular}




\begin{tabular}{|c|c|c|}
\hline Application & Location & Description/Function \\
\hline $\begin{array}{l}\text { A Modern Tunnel at } \\
\text { King's Cross }\end{array}$ & London, UK & $\begin{array}{l}\text { An Artistic LED-lit Tunnel connecting the crowded commute between } \\
\text { King's Cross and St. Pancras International. }\end{array}$ \\
\hline $\begin{array}{l}\text { Growing } \\
\text { Underground }\end{array}$ & London, UK & $\begin{array}{l}\text { Located 33m below the busy streets of Clapham, and with the use of } \\
\text { hydroponic systems and LED technology, crops are grown in the } \\
\text { perfect controlled environment of what used to be forgotten tunnels. }\end{array}$ \\
\hline $\begin{array}{l}\text { The House of Vans } \\
\text { Skatepark }\end{array}$ & London, UK & $\begin{array}{l}\text { To bring communities of the area together, the subterranean } \\
\text { skatepark was built and is spacious enough so that skateboarders can } \\
\text { spend a lot of time practicing. }\end{array}$ \\
\hline The Vaults Theatre & London, UK & A theatre located under the railway arches beneath Waterloo Station. \\
\hline $\begin{array}{l}\text { Temppeliaukio } \\
\text { Church }\end{array}$ & $\begin{array}{l}\text { Helsinki, } \\
\text { Finland }\end{array}$ & $\begin{array}{l}\text { A church excavated directly into solid rock, providing it with excellent } \\
\text { acoustics that made the church a popular venue for concerts. }\end{array}$ \\
\hline $\begin{array}{l}\text { Itäkeskus } \\
\text { Swimming Hall } \\
\text { and Civil Defense } \\
\text { Shelter }\end{array}$ & $\begin{array}{l}\text { Helsinki, } \\
\text { Finland }\end{array}$ & $\begin{array}{l}\text { The underground swimming hall and gym have facilities on two levels } \\
\text { that can accommodate around a thousand visitors at a time. Quarried } \\
\text { out of the solid rock, the hall can be converted into an emergency } \\
\text { shelter. }\end{array}$ \\
\hline $\begin{array}{l}\text { Arena Center } \\
\text { Hakaniemi and } \\
\text { Leikkiluola Indoor } \\
\text { Playground }\end{array}$ & $\begin{array}{l}\text { Helsinki, } \\
\text { Finland }\end{array}$ & $\begin{array}{l}\text { Located } 30 \mathrm{~m} \text { below Hakaniemi Market, the facility has four indoor } \\
\text { courts for playing floorball, futsal, handball, and badminton. }\end{array}$ \\
\hline $\begin{array}{l}\text { Formula Center } \\
\text { Helsinki }\end{array}$ & $\begin{array}{l}\text { Helsinki, } \\
\text { Finland }\end{array}$ & $\begin{array}{l}\text { An indoor karting center in Myllypuro. It is the only subterranean } \\
\text { karting track in Finland, and possibly in the world. }\end{array}$ \\
\hline Amos Rex & $\begin{array}{l}\text { Helsinki, } \\
\text { Finland }\end{array}$ & New underground art and urban culture exhibition spaces. \\
\hline $\begin{array}{l}\text { Viikinmäki } \\
\text { Wastewater } \\
\text { Treatment Plant }\end{array}$ & $\begin{array}{l}\text { Helsinki, } \\
\text { Finland }\end{array}$ & $\begin{array}{l}\text { A wastewater treatment plant built into the bedrock in Viikinmäki, } \\
\text { treating the wastewater from around } 800,000 \text { residents. }\end{array}$ \\
\hline $\begin{array}{l}\text { Underground Heat } \\
\text { Pump }\end{array}$ & $\begin{array}{l}\text { Helsinki, } \\
\text { Finland }\end{array}$ & $\begin{array}{l}\text { Excavated into the bedrock situated beneath Katri Valan Puisto public } \\
\text { park, it is the world's largest heat pump plant that combines both } \\
\text { district heat and cooling in the same process. }\end{array}$ \\
\hline $\begin{array}{l}\text { Underground } \\
\text { Reservoirs }\end{array}$ & $\begin{array}{l}\text { Helsinki, } \\
\text { Finland }\end{array}$ & $\begin{array}{l}\text { Underground reservoirs beneath Esplanade Park, holding } 35 \text { million } \\
\text { liters of water for the local energy company Helen. }\end{array}$ \\
\hline $\begin{array}{l}\text { Pionen, White } \\
\text { Mountain }\end{array}$ & $\begin{array}{l}\text { Stockholm, } \\
\text { Sweden }\end{array}$ & $\begin{array}{l}\text { Located } 30 \mathrm{~m} \text { underground, a Swedish atomic bomb shelter was } \\
\text { transformed to the headquarters for the Swedish internet server } \\
\text { provider, Bahnhof, hosting server halls and offices. }\end{array}$ \\
\hline $\begin{array}{l}\text { Filmstaden } \\
\text { Bergakungen }\end{array}$ & $\begin{array}{l}\text { Gothenburg, } \\
\text { Sweden }\end{array}$ & $\begin{array}{l}\text { To minimize the use of land, the project added underground cinema } \\
\text { halls to the entertainment center in Gothenburg. }\end{array}$ \\
\hline Dalhalla & Rättvik, Sweden & $\begin{array}{l}\text { A rock amphitheater that was built in a discontinued limestone } \\
\text { quarry in a forest. The underground location protected it from noise } \\
\text { pollution from roads and industries. }\end{array}$ \\
\hline Hallandsås Tunnel & $\begin{array}{l}\text { Skåne County, } \\
\text { Sweden }\end{array}$ & $\begin{array}{l}\text { Part of the expansion of the Swedish rail network, this project enabled } \\
\text { the payload of goods trains to be doubled, and allowed trains to run } \\
\text { at a speed of } 200 \mathrm{~km} / \mathrm{h} \text { compared with the previous } 80 \mathrm{~km} / \mathrm{h} \text {. }\end{array}$ \\
\hline West Link & $\begin{array}{l}\text { Gothenburg, } \\
\text { Sweden }\end{array}$ & $\begin{array}{l}\text { Upon its completion in } 2026 \text {, this } 8-\mathrm{km} \text { railway line, of which } 6 \mathrm{~km} \text { are } \\
\text { in a tunnel, will increase the capacity of the railway system in the } \\
\text { Gothenburg region that has already reached its maximum capacity. }\end{array}$ \\
\hline
\end{tabular}




\begin{tabular}{|c|c|c|}
\hline Application & Location & Description/Function \\
\hline $\begin{array}{l}\text { Norsborg Metro } \\
\text { Depot }\end{array}$ & $\begin{array}{l}\text { Stockholm, } \\
\text { Sweden }\end{array}$ & $\begin{array}{l}\text { The underground depot is one of the largest of its kind in northern } \\
\text { Europe, and was founded to accommodate the upgrade in the } \\
\text { Stockholm metro system, with limited space above ground. }\end{array}$ \\
\hline Stigbergsgaraget & $\begin{array}{l}\text { Stockholm, } \\
\text { Sweden }\end{array}$ & $\begin{array}{l}\text { As } 15 \text { percent of road surfaces in Stockholm are used for parking, this } \\
\text { three-story car park was built entirely in rock to replace roadside } \\
\text { parking with underground car parking. }\end{array}$ \\
\hline $\begin{array}{l}\text { Arlanda Airport } \\
\text { Underground } \\
\text { Railway Stations }\end{array}$ & $\begin{array}{l}\text { Stockholm, } \\
\text { Sweden }\end{array}$ & $\begin{array}{l}\text { With a total of } 5 \text { million journeys per year, this subterranean railway } \\
\text { line connects central Stockholm with Arlanda Airport, Sweden's } \\
\text { busiest airport. }\end{array}$ \\
\hline $\begin{array}{l}\text { Henriksdal } \\
\text { Wastewater } \\
\text { Treatment Plant }\end{array}$ & $\begin{array}{l}\text { Stockholm, } \\
\text { Sweden }\end{array}$ & $\begin{array}{l}\text { Built in the } 1930 \mathrm{~s} \text {, it is the first wastewater treatment plant in the } \\
\text { world to be built in rock. Having the facility built underground } \\
\text { allowed it to be extended later, without using up valuable land. }\end{array}$ \\
\hline $\begin{array}{l}\text { Arts Expansion at } \\
\text { Gammel Hellerup } \\
\text { High School }\end{array}$ & $\begin{array}{l}\text { Copenhagen, } \\
\text { Denmark }\end{array}$ & $\begin{array}{l}\text { An art school beneath a football field that joins the underground } \\
\text { gymnasium with a courtyard on its roof. }\end{array}$ \\
\hline $\begin{array}{l}\text { Recycling Center as } \\
\text { Neighborhood } \\
\text { Asset }\end{array}$ & $\begin{array}{l}\text { Copenhagen, } \\
\text { Denmark }\end{array}$ & $\begin{array}{l}\text { A recycling center built beneath a green hill with fitness facilities, } \\
\text { running tracks, and picnic areas. }\end{array}$ \\
\hline $\begin{array}{l}\text { Underground } \\
\text { Parking Katwijk } \\
\text { aan Zee }\end{array}$ & $\begin{array}{l}\text { Katwijk aan Zee, } \\
\text { Netherlands }\end{array}$ & $\begin{array}{l}\text { An underground parking garage that holds } 663 \text { parking spots, with } \\
\text { the aim to protect the coastline. }\end{array}$ \\
\hline $\begin{array}{l}\text { Parking Lot D. } \\
\text { Diogo de Menezes } \\
\text { Square }\end{array}$ & $\begin{array}{l}\text { Cascais, } \\
\text { Portugal }\end{array}$ & $\begin{array}{l}\text { An underground parking that was found as a solution to the lack of } \\
\text { large public spaces, as well as to stand out the stonewall of the } \\
\text { adjacent Citadel fortress. }\end{array}$ \\
\hline $\begin{array}{l}\text { Hanna Arendt } \\
\text { Underground } \\
\text { School }\end{array}$ & Bolzano, Italy & $\begin{array}{l}\text { Four levels excavated } 17 \text { meters below the ground on which } 9 \\
\text { classrooms, } 6 \text { workshops, a winter garden, and a utility room are } \\
\text { distributed. }\end{array}$ \\
\hline $\begin{array}{l}\text { Underground } \\
\text { Expansion of Städel } \\
\text { Museum }\end{array}$ & $\begin{array}{l}\text { Frankfurt, } \\
\text { Germany }\end{array}$ & $\begin{array}{l}\text { A } 12,270 \text { square meter subterranean gallery with } 195 \text { windows to } \\
\text { allow the sunlight to stream in. }\end{array}$ \\
\hline Salina Turda & Turda, Romania & $\begin{array}{l}\text { An underground salt mine that has been converted into a fully } \\
\text { functional museum. }\end{array}$ \\
\hline $\begin{array}{l}\text { Post Office in The } \\
\text { Postojna Caves }\end{array}$ & $\begin{array}{l}\text { Postojna, } \\
\text { Slovenia }\end{array}$ & $\begin{array}{l}\text { Named } 1 \text { of } 7 \text { Subterranean Wonders of The World, the world's first } \\
\text { cave post office opened its doors in } 1899 \text { and is still operating till this } \\
\text { date. }\end{array}$ \\
\hline Sancaklar Mosque & Istanbul, Turkey & An underground worship hall located in a prairie landscape. \\
\hline PATH & $\begin{array}{l}\text { Toronto, } \\
\text { Canada }\end{array}$ & $\begin{array}{l}\text { A } 30 \mathrm{~km} \text { long network of walkways and shopping areas. Used daily by } \\
\text { over } 200,000 \text { residents and workers, it is the world's largest } \\
\text { underground shopping complex with } 371,600 \text { square meters of retail } \\
\text { space. }\end{array}$ \\
\hline $\begin{array}{l}\text { Underground City } \\
\text { (RÉSO) }\end{array}$ & $\begin{array}{l}\text { Montreal, } \\
\text { Canada }\end{array}$ & $\begin{array}{l}\text { A } 33 \mathrm{~km} \text { long network connecting } 1,700 \text { boutiques, } 200 \text { restaurants, } \\
\text { universities, movie theatres, apartments, metro stations, art centers, } \\
\text { museums, and more complexes, all being beneath downtown } \\
\text { Montreal. }\end{array}$ \\
\hline $\begin{array}{l}\text { Tunneled Sneaker } \\
\text { Store }\end{array}$ & $\begin{array}{l}\text { Melbourne, } \\
\text { Australia }\end{array}$ & $\begin{array}{l}\text { The store design features a circular entrance, floor-to-ceiling shelving, } \\
\text { polished concrete floors, and dimmed lighting, all giving a futuristic } \\
\text { appearance to this tunneled store. }\end{array}$ \\
\hline
\end{tabular}




\begin{tabular}{|l|l|l|}
\hline Application & Location & Description/Function \\
\hline $\begin{array}{l}\text { Underground } \\
\text { Hospitals }\end{array}$ & Syria & Act as fortified facilities for treating patients in conflict areas. \\
\hline Casa Brutale & Faqra, Lebanon & A residence built into the mountainside at an altitude of 1,600 meters. \\
\hline
\end{tabular}

\section{Conclusion}

A comprehensive strategy must be implemented in planning for urban underground space. Successful execution requires an interdisciplinary approach with actors from various disciplines contributing to the planning of urban underground space projects. This paper demonstrated various real-world applications of underground space utilization to help alleviate surface congestion associated with rapid urban growth.

\section{Compliance with ethical standards}

\section{Acknowledgments}

We would like to acknowledge past researchers who have contributed to advancements in underground space.

\section{Disclosure of conflict of interest}

There is no conflict of interest.

\section{References}

[1] United Nations. World Urbanization Prospects 2018. United Nations Department of Economic and Social Affairs, New York. 2009.

[2] Schneider A, CM Mertes. Expansion and growth in Chinese cities, 1978-2010, Environmental Research Letters. 2014; 9(2): 024008.

[3] Bai X, P Shi, L Yansui. Society: Realizing China’s urban dream, Nature. 2014; 509(7499): 158-160.

[4] PopulationStat. Beijing, China population. 2020.

[5] Routley N. Meet China's 113 cities with more than one million people”, Visual Capitalist, February 6, Vancouver, Canada. 2020.

[6] Sterling RL. Underground technologies for livable cities." Tunnelling and Underground Space Technology. 1997; 12(4): 479-490.

[7] Bobylev N, RL Sterling. Urban underground space: A growing imperative. Tunnelling and Underground Space Technology. 2016; 55: 1-4.

[8] Munfah N. Utilization of underground space promotes urban development. Tunnel Business Magazine, October, Benjamin Media, Brecksville, OH. 2020; 10-13.

[9] Besner J. Underground space needs an interdisciplinary approach. Tunnelling and Underground Space Technology. 2016; 55: 224-228.

[10] Gilbert PH, ST Ariaratnam, NR Connery, G English, C Felice, Y Hashash, C Hendrickson, P Nelson, R Sterling, G Tamaro, F Tonon. Underground Engineering for Sustainable Urban Development, The National Academies Press, Washington, DC. 2013.

[11] Sterling RL. Planning for cost-effective underground space use in urban areas. (1st ed., pp. 51-60) CRC Press. 2000.

[12] Nelson PP. A framework for the future of urban underground engineering. Tunnelling and Underground Space Technology. 2016; 55: 32-39.

[13] Bobylev N. Transitions to a High Density Urban Underground Space. Procedia Engineering. 2016; 165: $184-192$.

[14] Bobylev N. Mainstreaming sustainable development into a city's master plan: A case of urban underground space use. Land Use Policy. 2009; 26(4): 1128-1137. 
[15] Bartel S, G Janssen. Underground spatial planning - Perspectives and current research in Germany. Tunnelling and Underground Space Technology. 2016; 55: 112-117.

[16] Bobylev N. Underground space in the Alexanderplatz area, Berlin: Research into the quantification of urban underground space use. Tunnelling and Underground Space Technology. 2010; 25(5): 495-507.

[17] Yang L, RL Sterling. Underground space use and urban planning in Shanghai. Journal of Urban Planning and Development, ASCE. 1998; 114(1): 34-49.

[18] Cui J, D Lin. Utilisation of underground pedestrian systems for urban sustainability. Tunnelling and Underground Space Technology. 2016; 55: 194-204.

[19] Santamouris M. Heat island research in Europe: the state of the art. Advances in Building Energy Research. 2007; 1(1): 123-150.

[20] Akbari H, C Cartalis, D Kolokotsa, A Muscio, AL Pisello, F Rossi, M Santamouris, A Synnefa, NH Wong, M Zinzi. Local climate change and urban heat island mitigation techniques - the state of the art, Journal of Civil Engineering and Management. 2016; 22(1).

[21] Phelan P, K Kaloush, M Miner, J Golden, B Phelan, H Silva, R Taylor. Urban heat island: mechanisms, implications, and possible remedies Annual Review of Environment and Resources. 2015; 40: 285-307.

[22] Han A, A Cornaro. Future cities, resilient cities - the role of underground space in achieving urban resilience", Underground Space. 2019; 5(3).

[23] Brown G. A global sand shortage could cause damaging effects to our rapidly urbanizing world." Business Insider. 16 January 2020.

[24] Ariaratnam ST, K Piratla, A Cohen, M Olson. Quantification of sustainability index for underground utility infrastructure projects." Journal of Construction Engineering and Management, ASCE. 2013; 139(12).

[25] Bobylev N. Underground space as an urban indicator: measuring use of subsurface. Tunnelling and Underground Space Technology. 2016; 55: 40-51. 